\title{
Exposure Elapsed Time
}

National Cancer Institute

\section{Source}

National Cancer Institute. Exposure Elapsed Time. NCI Thesaurus. Code C83281.

The interval between two exposure reference time points. 